\title{
From an Intelligence Tower to a Tower of Joy: The Story of Havran in the Former Iron Curtain Buffer Zone
}

\author{
Jiří Woitsch - Karolína Pauknerová
}

DOI: 10.21104/CL.2019.4.01

\begin{abstract}
The article is a case study of Havran, a former military intelligence tower located in Western Bohemia in the former Iron Curtain buffer zone. It focuses especially on the process of Havran's transformation from a military installation to a ruin and finally into a lookout tower and Iron Curtain memorial. The study tracks the changes in the tower's physical structures and exhibition content. The goals are to present an analysis of forming a special type of heritage and to review and discuss the processes of negotiating the meaning of the landscape, demonstrated on the site with the tower. Methods used include historical archive research, review of internet fora and media articles as a specific data source for changes in the tower, and basic qualitative content analysis for the exhibition currently located at the lookout tower.
\end{abstract}

\section{Key words}

Czech Republic, Havran tower, Iron Curtain, Cold War, military installation, heritage, landscape

\section{Acknowledgment}

Institutional support RVO 68378076, the Institute of Ethnology of the Academy of Sciences of the Czech Republic; The Progres programme, Transdisciplinary research of the Anthropocene (Q50), Charles University; University Research Centre, Nature and Culture: Historical, Cultural, and Biological Concepts of Human Nature (UNCE 204 056), Charles University.

\section{Contact}

PhDr. Jiří Woitsch, Ph.D., Institute of Ethnology of the Czech Academy of Sciences, Na Florenci 3, 11000 Praha 1, Czech Republic, e-mail: jiri. woitsch@post.cz;

Mgr. et Mgr. Karolína Pauknerová, Ph.D., Charles University, Center for Theoretical Study, Husova 4, 11000 Praha 1, Czech Republic, e-mail: pauknerova@cts.cuni.cz.

\section{Jak citovat / How to cite}

Woitsch, Jiří - Pauknerová, Karolína. (2019). From the Intelligence Tower to the Tower of Joy: The Story of Havran in the Former Iron Curtain Buffer Zone. Českýlid 106, 409-437. doi:http://dx.doi.org/10.21104/CL.2019.4.01 


\section{Introduction}

Havran hill (Großer Rabenberg in German) is situated in the Upper Palatine Forest and is the highest peak in the Primda Forest $(894 \mathrm{~m}$ above sea level, GPS: $49.74300 \mathrm{~N}, 12.40891 \mathrm{E})$. It is located in the immediate vicinity of the Czech-German (Bavarian) state border, about $16 \mathrm{~km}$ southwest of the town Tachov, $9 \mathrm{~km}$ west of the village Lesná and $2 \mathrm{~km}$ west of the abandoned village Zlatý Potok (Goldbach). We first encountered the ruin of Havran tower during our previous project conducted in 20122014, led by Jiří Woitsch as principal investigator, which was focused on cultural heritage and memory in the borderland region deeply affected by the transfer of Czech Germans after World War II and the very existence of the Iron Curtain buffer zone. ${ }^{1}$ The project also explored the semantic significance of places near the village Lesná, which is currently the closest permanently inhabited village on the Czech side of the border. The list of places was compiled using the method of Free-listing (for methodology see Brewer 2002 and Bernard 2006: 299 quoted in Zíková - Fatková 2014: 205-206). Among all the places Havran was in the first position in frequency (i.e. the most frequently named by research partners) and second in Smith's index. It belonged to the group of the most important, collectively shared sites of the Lesná inhabitants (Zíková - Fatková 2014, here specifically pages 206 and 208). Discovering this extraordinary significance of the hill and the ruins found on it led us to perform more systematic research later on, focusing on the history of this locality, especially during the Cold War, the tourist infrastructure in the region (Pauknerová - Woitsch 2016) and the transformation of Havran from a secret and strictly guarded military installation into a tourist location.

Here, we present a case study of Havran focused especially on this process of transformation from an intelligence tower to a ruin and finally into a lookout tower and Iron Curtain ${ }^{2}$ memorial. The study is focused on changes in the physical structures of the tower and exhibition content rather than on local or tourist views on the process and exhibition. Our goals are to present a case study of forming a special type of heritage, to review and discuss processes of negotiating the meaning of the landscape,

1 Sídelní a krajinný prostor jako odraz kulturního dědictví a paměti národa, University of West Bohemia in Pilsen, supported from the NAKI programme, project website: http://www.antropologie.org/cs/vyzkum/zakladni-vyzkum/ sidelni-a-krajinny-prostor-jako-odraz-kulturniho-dedictvi-a-pameti-naroda.

2 The term 'Iron Curtain' is used in two meanings: it is the infrastructure securing the border itself (e.g. fences) as well as the whole body of practices and meanings connected with guarding the border, influencing the lives of people living in its vicinity and elsewhere. 
demonstrated on the site with the tower. As methods we used historical archive research, review of internet fora and media articles as a specific data source for changes in the tower, and basic qualitative content analysis for the exhibition currently located at the lookout tower. Finally, our results are also based on ethnographic fieldwork on site: repeated visits to the site before and after the reconstruction in 2012-2014, 2016 and 2019.

\section{Havran hill and the Tachov borderland: a short history}

The colonization of the borderland region began by the early 8th century and slowly continued until the 12 th century; the new settlers spoke mostly German (Schuster 1962; Köferl 1890, for general context and modern interpretations see Fatková et al. 2014). In the 12th and 13th century, the border between Bohemia, Upper Pfalz and Bavaria stabilized and ran in the imaginary centre of the untouched frontier forest. The new city Tachov was founded by Ottokar II of Bohemia after 1270 (the first written mention of it is from 1285). The colonization of the large royal estate of Tachov was subsequently roughly completed in the 14th century. Significant changes to the development of the settlement structure and landscape occurred after 1598, when the royal estate in the border forest was sold and the forests stopped serving as a natural boundary and began to be heavily colonized and economically exploited. The glassmaking industry, potash making, highly developed forestry and iron production were the most important industries in the region up to the 20th century (Hofmann 1991; Hlávka - Kadera 2010; Procházka 2009).

In the 19th and early 20th century, the Tachov region was linguistically and ethnically almost homogeneous. The vast majority of the local population declared German as their mother tongue in censuses and later reported their nationality as German. In 1921, out of the total of 24,896 inhabitants 24,385 of them declared German nationality in the judicial district of Tachov. A small Czech minority was formed after 1918, especially in Tachov and Rozvadov, consisting mostly of government employees and officials. The Jewish minority, destroyed during World War II, was much more significant both statistically and culturally. The Tachov borderland witnessed a downturn as early as the 1800 s, mainly due to the decline of glassmaking and other industries, and slowly became a marginalized region faced with depopulation and a number of other socioeconomic problems.

After World War II the German majority was expelled, and there was an attempt to repopulate the area with Czechoslovak citizens and immigrants from abroad. Small parts of the German population managed to 
leave their homes with their property even before the organized transfer began; the remaining Germans were later gathered at transit centres (camps) in Tachov. The transfer itself started in spring 1946 (Hamperl 1996; Staněk 1991). In the spring of 1948 after the Communist takeover, only 481 Germans remained in the Tachov region. After the expulsion of Germans, the Tachov borderland area was gradually resettled, although the West Bohemian borderland was not as attractive for Czech-speaking migrants from the interior as other regions (Kotrbatá 2010). Mainly Ruthenians from Romania and Slovakia settled in the village of Lesná, while migrants from other Eastern European countries were originally settled in many other municipalities within the Tachov region (Petrášová 1984; Petrášová 1985).

The intensification of border surveillance and creation of a heavily militarized landscape started in 1948 in the Tachov region (Edl 2013; Pulec 2001). In June 1951, as part of the re-organization of the border guarding regime, a two-kilometre strip running along the border was declared a protected zone ('zakázané pásmo') and a restricted zone ('hraniční pásmo') extended farther inland, and construction of the Iron Curtain began. However, given that the Tachov borderlands form a salient extending into Germany, the Iron Curtain was built 'economically' and much farther from the border itself. Hence, the protected and restricted zones in the Tachov region were sometimes as much as $10 \mathrm{~km}$ wide and created a 'no man's land' encompassing square kilometres in the double digits. Havran tower was built in the middle of this no man's land in the late 1960s (Ilčík 2013: 264-369; Ilčík 2017/2: 185-190). Clearing of only recently resettled villages began in November 1951 in the protected and restricted zones. A series of demolitions of abandoned buildings undertaken by the army, civilian staff and volunteers took place in 1953-1957, followed by a 'nationwide demolition' between May 1959 and October 1960, during which a total of 37,698 buildings was destroyed all over Czechoslovakia (Kovařík 2006). This last phase of demolitions was centrally organized and managed by the Ministry of the Interior and its aim was to remove all abandoned buildings in the border regions both for security and propaganda reasons. In the Tachov region, this led to the ultimate demolition of over 30 villages and hamlets and hundreds of other cultural landscape elements including many historical monuments. Only extensive agriculture and forestry was allowed in the protected zone, contributing to the rewilding of the landscape within a short period (Hamperl 2004; Procházka 2011).

In 1951, it was also decided to build the engineering-technical border security system ('ženijně-technické zabezpečení hranic'), which was the 
most dangerous type of Iron Curtain installation (Vaněk 2004). In the first phase, several meters of forest were cleared along the border and a fence with barbed wire under high voltage and minefields were put up. A signal wall was introduced in 1956 with a short-circuit reaction to disturbance, warning of movement in the area. Experience with border surveillance led to a change in the whole concept and the rebuilding of the Iron Curtain in the mid-1960s. The high-voltage fence was removed by 1965 and all fences were moved further inland to ensure more effective capture of people attempting to escape Czechoslovakia. A signal wall was created, a $220 \mathrm{~cm}$ barbed wire fence powered by a light current that gave the watch a signal in the event of any disruption. In front of the main fence was a 5-6 m wide strip of ploughed land and another fence in front of that preventing wild animals from entering. The new system somewhat decreased the range of the buffer zone.

As described, the Iron Curtain gradually changed several times and included a large number of facilities of various types: a barbed wire barricade (until 1965 under deadly high voltage), observation points, minefields, signal walls, service roads, lights, bunkers and other fortifications, barricades and fences against vehicles and tanks, etc. Moreover, large barracks, garrisons, camps and training facilities for border guard troops were built along the border. The spacing between the garrisons was about 5-10 km, which made it possible for pedestrian and motorized patrols to guard the border effectively (Jílek - Jílková 2006; Dubánek et al. 2011: 77-91; Stručný prehled 1986).

The border guards ('Pohraniční stráž') were in charge of guarding the borders and all the facilities of the Iron Curtain. This armed force was created in 1951 based on the Soviet model - its organization, command, weapons and equipment were military in character, border guard officers were professional soldiers, and the men were compulsory military service recruits. However, the border guards were not under the command of the Czechoslovak army, but the Ministry of the Interior. Naturally, the military system of guarding the border contributed to the extreme militarization of everyday life in the border region, which was very close to the 'regular' army zones (Pulec 2006). However, there was both co-operation and considerable rivalry and tension on the level of necessary everyday contact between the army, which was also present in the borderland regions, and the border guards, which is essential for our study in the Tachov region (ABS 329).

The Iron Curtain fell in the Tachov region even before the end of 1989 and its most important components (particularly the observation towers and barbed wire barricades) were removed in 1990. However, a number 
of substantial material relics of the Iron Curtain remain in the landscape to this day. The scarred landscape of the Tachov region was subsequently opened to visitors after 1989 and there were several attempts to restore some monuments in the former German communities (esp. cemeteries). Currently, the Tachov region could benefit mainly from tourism, which would be linked to the well-preserved natural environment. The Bohemian Forest ${ }^{3}$ was declared a Protected Landscape Area by the government on January 12, 2005, in effect as of August 1, 2005. This type of nature protection is less strict than national parks, for instance, but landscape management must be carried out according to the zones of graded protection so as to preserve and improve the natural conditions of the region and create optimum ecological functions in these territories. Recreational use is possible, provided that it does not damage the natural value of the protected landscape. The total protected area is $473 \mathrm{~km}^{2}$ with a number of small highly protected areas within. However, tourism in the northern part of the Bohemian Forest / Upper Palatine Forest is developing very slowly due to insufficient infrastructure; there are marked hiking trails, but almost no accommodation facilities, restaurants etc.

\section{The tower as a military and post-military installation}

For centuries Havran was an absolutely unimportant hill, lost in the middle of the border forests, permanently overgrown with vegetation, suffering from strong winds and harsh winters and with no road or path leading to it from the Czech or from the German side. About $1 \mathrm{~km}$ east of Havran was a small settlement with only two houses called Skláře (Neu Windischgrätz, in the 1830s a large glassmaking village), which was abandoned and demolished after 1945, while a border guard garrison was built on the same site in 1951 and served until 1966 (ABS 1335-1340, Slavíková - Vaněk 2008: 2-26).

The Czechoslovak army arrived in this forgotten corner of the borderland behind the Iron Curtain in the early 1960s, and built a unique military installation - the Havran tower (unless otherwise stated, the following text is based on Ilčík 2013: 250-314; Ilčík 2017/2: 4-6, 10-15, 169242). As electronic (radio, radar, etc.) intelligence, surveillance, jamming, interception and generally speaking electronic warfare developed rapidly in the 1960 s, and taking into account the politically bifurcated world of

3 The geographical name 'Bohemian Forest' is a literal translation of the current Czech name of the area 'Český les', used also by local organizations. However, the correct and official English translation should be 'Upper Palatine Forest', which is equivalent to the German name of the area - 'Oberpfälzer Wald'. 
the time, it is no surprise that the Czechoslovak army's electronic warfare tasks were performed at small and highly secret military bases located at important elevation sites as close as possible to the 'Western enemies' in the Czechoslovak borderlands. Construction of these bases began in the 1960s and improvements to them continued until the end of the Cold War. They were operated by special military reconnaissance units. The main purpose of Havran and several other similar towers was to track military radio targets, such as radars, army identification systems, and aircraft navigation systems belonging to the NATO alliance. The range of modern facilities in the 1980 s was up to 500 kilometres.

A military road and the first 20-meter wooden tower were built on Havran in 1963, while the platoon of approx. 30 soldiers from the military radio-technical reconnaissance brigade from Zbiroh in central Bohemia was housed in the border guard garrisons in Skláře. Between 1967 and 1972, a major reconstruction and modernization took place, and a massive tower with a base of $8 x 8$ meters and a total height of 46 meters was built at the top of the hill; 25 meters of the tower consisted of a steel structure which was followed by a wooden antenna superstructure (Figure 1). In and around the tower there was space for radars, antennas and receivers, as well as extensive infrastructures including a service station, accommodations, a kitchen, a boiler room, garages and sanitary facilities. However, the base never served as permanent housing for troops. In the 1960s troops stayed in the border guard garrison in Skláře, as mentioned above, while starting in the 1970s soldiers had to be regularly transported from barracks several kilometres away in Lesná, Tachov and even Mariánské Lázně. Another gradual reconstruction was planned and even started in the late 1980s, but was never finished due to the change in political and military circumstances in Europe. The tower itself was used and managed in some way by the Czechoslovak and later Czech army until 1992/1993; shortly after it was totally abandoned and fell into dangerous disrepair due to the harsh natural conditions, vandalism and theft (Figure 2). During the 1990s and especially after 2000, the Czech army, which still owned the tower and nearby grounds, offered the tower for sale and later also for free transfer to nearby municipalities. After the last attempted free-ofcharge transfer in 2008 failed, a tender was announced in October 2009 for a company to demolish the tower. However, the army had to cancel the demolition and save the money for other purposes as a result of the economic crisis, and in 2011 a new future opened for the Havran tower, as described later in this article.

As we can see, in the early 1960s a highly specialized military facility was built at Havran, which was part of the Warsaw Pact's extensive elec- 
tronic warfare system. Like other bases along the western Czechoslovak border, Havran was located in the protected buffer zone along the border, which along with the restricted zone formed an extremely wide swathe across the Tachov region. The base was run by an elite and 'top secret' unit of the Czechoslovak army and never had anything to do with guarding the Iron Curtain. This point must be particularly emphasized in relation to its recent 'heritagization' and its contemporary presentation.

On the other hand, as written documents (ABS 357-359, 1335-1340) and the accounts of former soldiers and border guards (Ilčík 2013: 303-308, http://www.vojensko.cz/stanoviste-havran [online, retrieved 2019-02-05]; Hř́bal 2014) show, the placement of the Havran tower and base in 'no man's land' brought a number of unusual and absurd situations. These were mainly caused by the paranoid secrecy surrounding everything related to the purpose and operation of Havran tower by the military, contrasted with the strict supervision of everything including the army in the border zone. Soldiers who served at Havran tower, for example, underwent detailed checks and needed special passes to the protected zone. When the base was first opened, the soldiers, as stated above, were housed in the nearby garrisons in Skláre and walked regularly to the Havran base, passing under high-voltage fences through special tunnels. Only for larger automobile transports was the voltage switched off. Behind the Iron Curtain they could move relatively freely and were only occasionally checked by the border guard patrols.

The situation, however, changed substantially after the Soviet occupation of Czechoslovakia, when Sergeant Emil Chmelař fled from Havran to Germany on August 31, 1968 (ABS 362). Soldiers' accommodation in Skláře was cancelled, the Iron Curtain was moved further from the border, and Havran soldiers were strictly controlled and guarded, and the base itself was protected by a simple fence. This did not prevent further desertion from the neighbouring Dylen tower, so a double barbed wire wall was built at Havran in the 1980s, even more thorough than the "normal' Iron Curtain. Guard dogs ('samostatně útočící pes - SUP') moved in the space between the fences, discharging from automatic pens when the fences were disrupted. As a result, the elite and secret army units were enclosed in a kind of prison carefully guarded by the border guards. At the same time, the interplay between these two military bodies (border guards and Czechoslovak army) could be very tense, with numerous minor incidents, humiliating inspections on border guards' posts, etc. On the other hand, day-to-day interaction could also be positive, as shown by memories of shared free time, military jokes, and so on. The consequence of strict secrecy is that the border guards had no idea of the purpose of the 
tower on Havran, and the means of guarding the Iron Curtain remained hidden from ordinary soldiers. This two-sided ignorance persisted sometimes even after 2000 as recent online discussions among former soldiers and border guards show (http://www.vojensko.cz/stanoviste-havran [retrieved 2019-02-05]).

\section{The tower and heritage}

The relics of the Cold War have been transformed into tourist attractions in many places, not only along the former Iron Curtain as in our case. ${ }^{4}$ In the present Havran lookout tower some parts and features of the original tower have been preserved, and some have not. The ruined military tower started its new life as a specific type of heritage, or, one might say, underwent the process of 'heritagization'. By that we do not mean formal heritage protection or even inclusion of the tower on the list of official heritage sites at the National Heritage Institute, ${ }^{5}$ but simply the fact that the tower attracted the attention of people who decided to save it and present it to the public, and in this sense the tower is part of the national heritage.

Ethnological or ethnology-related research of the Cold War has been summarized for Czech readers by the co-author of this article Jiř́ Woitsch (Woitsch 2016). Here we are mostly interested in symbolic and material remains or representations of the theme (Woitsch 2016: 17-18). Some of the remains of the Cold War are famous and have a second life as a symbol such as the Berlin Wall (e. g. Drechsel 2010) or the Iron Curtain as a whole (Eckert 2011). The Cold War is a topic studied in terms of its remembrance (Lowe - Joel 2013) as well as within archaeological research (Schofield - Cocroft 2009) and we are specifically interested in its role as heritage (Schmidt - von Preuschen 2005; for European ethnology and heritage see Janeček 2015). Other contexts for such studies include military landscapes (Pearson 2012; Pearson et al. 2010; see also a special issue of Folklore: Electronic Fournal of Folklore 70, 2017) and the historical study of the Iron Curtain (in the Czech context e.g. Jílek et al. 2006).

4 On the heritagization of the Cold War period cf. Melinda Harlov-Csortán (Harlov-Csortán 2017) who describes the situation at the Hungary - Austria border, once a military zone, edge of the Iron Curtain and today an official UNESCO site.

5 The Central List of Cultural Monuments of the Czech Republic of the National Heritage Institute https://www.npu.cz/en/NPU-and-heritage-conservation/ historic-buildings-conservation-management/the-monument-fund/immovableheritage [retrieved 2019-02-18]. 
In this part we present selected theories related to the concept of heritage which serves us as a frame for the material and symbolic changes the tower underwent. ${ }^{6}$ Heritage seems to be closely connected with the past, yet it is the present when the heritage is acknowledged as something that has specific value. It is dependent on the present opinion on what constitutes a valuable remnant of the past. The concept of heritage is tightly connected with the present negotiation of the meaning of the past. We tend to understand the heritage not as something solid, not as a state, but rather as a process. Similarly, Laurajane Smith argues that:

Heritage is not a thing, site or place, nor is it 'found', rather heritage is the multiple processes of meaning making that occur as material heritage places or intangible heritage events are identified, defined, managed, exhibited and visited (Smith 2012, paragraph 2 of the online publication). ${ }^{7}$

When we focus on heritage, our view is as if turning towards the past. As if is crucial here, because the heritage is tightly connected with the present; it is established, presented and viewed in the present with its needs and opinions. Brian Graham and Peter Howard summarize:

Heritages are present-centred and are created, shaped and managed by, and in response to, the demands of the present. As such, they are open to constant revision and change and are also both sources and results of social conflict (Graham - Howard 2008: 2-3).

Currently it seems that interest in the heritage of the past is omnipresent. ${ }^{8}$ In the Czech Republic this can be seen both in top-down policies (e.g. various government documents supporting heritage protection) and bottom-up initiatives (highly popular educational trails and the growing number of various small, private museums and monuments). However, this does not necessarily mean that expert knowledge about the past is reaching a bigger audience. On the contrary, some authors like David W. Blight speak about 'a serious gulf between elite knowledge and the

6 For a comprehensive volume on heritage see Waterton - Watson (2015). For an unorthodox attitude towards heritage that has received substantial attention in recent years see a book about decay by Caitlin DeSilvey (2017). For heritage and identity see Graham and Howard (2008).

7 https://journals.openedition.org/nuevomundo/64148\#text [retrieved 201905-27].

8 This might have a connection with the image of an apocalyptic future, both environmental and political (for a discussion of both see Swyngedouw 2010). 
huge public interest in the past' (Blight 2009: 247). ${ }^{9}$ What is generally understood as heritage reflects the dominant group opinion, determining which projects get funding, etc. This is what Laurajane Smith referred to as 'authorized heritage discourse' (Smith 2006). However, society also contains other heritages that are not recognized by society as a whole, that are under negotiation, etc. (cf. Robertson 2016). Our relationship towards the past also includes negotiation of who is 'we' and who is 'them': 'The heritage site is a political resource and, as such, it aims to legitimize a specific social reality which divides people into "we" and "they" (Poria - Ashworth 2009: 522). The value of heritage is, according to Brian Graham and Peter Howard, placed upon it by people who view it through many lenses, the most obvious of which are: 'nationality; religion; ethnicity; class; wealth; gender; personal history; and that strange lens known as "insideness" (Graham - Howard 2008: 2)..$^{10}$

Yaniv Poria and Gregory Ashworth argue that 'heritagization is not about the past but about the use (and abuse) of the past to educate - and at times inculcate - the public' (Poria - Ashworth 2009: 523). Our paper is a contribution to the debate over this process. In our example of 'heritagization' we focused in the first part on the military history of the tower and now will follow up with an analysis of how its transformation into a tourist lookout tower was presented in the newspaper as compared to the presentation in situ.

\section{The lookout tower and monument}

After the Velvet Revolution in 1989, still in use by the army, the tower became a part of the newly open space in the formerly protected zone of the Iron Curtain. Gradually the military tower became a point on the green and blue hiking trails marked by Czech Tourist Club and also on

9 Blight puts this trend in a possible connection with the end of the clearly defined world, saying: 'If since the end of the clarity - the unities and certainties - of the Cold War (or since the great upheavals of the 1960s), we have experienced a breakdown in agreed-upon institutions, values, languages, or methods of cohesion, then this too may account, in part, for a growing social preoccupation with memory and identity. Perhaps many people for two and three decades now have been looking backward or inward, or for escapes into nostalgia and heritage they can possess, when looking ahead is no longer a source of confidence' (Blight 2009: 247).

10 For dissonant heritage and its reception by tourists in Polish borderlands see (Owsianowska 2017) and for a discussion of post-socialism and tourism after the fall of the Iron Curtain see (Banaszkiewicz et al. 2017: 112-114). 
cycle trails. It is a meeting point for former soldiers ${ }^{11}$ and a point on the trail of a cycling race.

The new life of the tower can be divided into several phases. In this part of the text we use media articles ${ }^{12}$ as a specific data source to illustrate the tower's journey from post-military structure towards tourist lookout tower and monument. In the first phase until 2008/2009, Havran represents an interesting tourist spot and when an article on Havran appears in the media, it often mentions that it would be worth having a tourist lookout tower there and that the tower is in pitiable condition. In newspaper articles such as 'Abandoned military tower is standing on Havran'13 from 2002 readers could learn that Havran hill is the highest peak in the middle part of the Upper Palatine Forest near the German border and upon it stands the ruin of a tower used for surveillance of the western border and that the relics of fences and barbed wire 'feel almost scary'. ${ }^{14}$ Here the author makes a very significant mistake when writing about the purpose of the tower, which was in fact meant for other purposes as described above in this paper. Another article mentions: 'It is a pity that the tower is decaying. When it falls down, maybe someone will realize how precious it was and will build a new lookout tower there for a lot of money. ${ }^{15}$ The author of another newspaper article recalls the time ' $[\mathrm{w}]$ hen the first maps and text information appeared after the Velvet Revolution about the border area of Tachov, still closed to the public and thus almost unknown, the name of the Havran hill almost magically extended'. He also mentions that 'the note that the (military) station would deserve to become a tourist lookout tower' was a particularly attractive point and that the beautiful view from the top of the ruin was 'a little spoiled by

11 See the website Vojensko.cz, which is managed and visited especially by former Czechoslovak military and border guards, who also contribute to many extensive online discussion fora there. The last meeting took place in September 2018: http://www.vojensko.cz/stanoviste-havran?fibre=127907\#vypisvlakna [retrieved 2019-02-05].

12 We reviewed the export from the database ANOPRESS, which is a multidisciplinary database focusing on monitoring Czech media back to 1996, available in the Library at the Czech Academy of Sciences in Prague. We used the keywords 'Havran <AND> Tachov' and the time period 2002-2018. The period was chosen to pre-date the Army decision to demolish the tower in 2009 and include rebuilding the tower and its opening in 2013-2014, its promotion in 2015 and what followed until the end of last year, 2018.

13 Translation into English by authors, if not stated otherwise.

14 Opuštěná vojenská věž stojí na Havranu / Abandoned military tower is standing on Havran, 2002.

15 Podél „železné opony” na Havran / Along the 'Iron Curtain' up to Havran, 2007. 
[his] feeling scared'.$^{16}$ Newspaper readers could also find an article about a visit to Havran with a former soldier who used to serve there, where the author also writes: 'When we were at the forestry administration to ask for permission to enter they told us that Havran would make a nice place for a lookout tower. ${ }^{17}$ An article from 2010 titled 'Trip to the Upper Palatine Forest' mentions only that the Havran tower has a sad destiny, as it has been abandoned. Other similar towers at Poledník, Čerchov, Velký Zvon, and Dyleň are either lookout towers or in private hands. The author says that climbing the tower is an adrenaline-pumping experience, but it is worth it. He also mentions preserved barbed wire 'recalling the times of the Iron Curtain ... Looking at them gives a person chills'. ${ }^{18}$

Another phase of media coverage came in 2009, when the Army decided to demolish the ruin of the tower, which moved people in the region to action, ultimately saving the tower and opening it to the public. These people - Jan Kárník, Miroslav Hověžák, Milan Volf and Pavel Janoušek founded the Tachov Military History and Sports Club ${ }^{19}$ and managed to get funding for the reconstruction. This situation is summarized in an article from 2011 titled 'Havran will not be demolished'. Havran is correctly described in that article as 'a decaying object of air defence of the state'. The article also mentions an unsuccessful attempt in 2008 to transfer the ruin to Lučina, an association of municipalities in the Tachov district. The pitiable state of the tower is described as 'decaying' and a threat to tourists. The main point of the article discussed the change in 2011: 'The new owner wants to make the structure into a lookout tower and an Iron Curtain memorial.' This new owner was the Club. The article also gives information about costs and ongoing negotiations over the future form of the tower and also the decision to have it open year-round and connect it with the nearby Silberhütte recreational area in Germany. ${ }^{20}$

In the words of Club member Jan Kárník, the Club was established in 2008 and aims to document the history of the Tachov region. Their long-term interest was to re-build and operate Havran as a public lookout tower. When the army decided to demolish the tower in 2009, the Club

16 Vrch Havran nahnal turistům pořádný strach / The Havran hill gave tourists a huge fright, 2008.

17 Havran chátrá, může tam jít o život / Havran is decaying, it can be lifethreatening, 2009.

18 Výlet na Šumavu / Trip to the Šumava (Bohemian Forest), 2010.

19 Klub vojenské historie Tachov (Tachov Military History Club) - Havran tower [retrieved 2019-03-05] http://rozhlednahavran.cz/web/kontakt/ The official name of the Club is the Tachov Military History and Sports Club; it is a voluntary association of citizens.

20 Havran se bourat nebude / Havran will not be demolished, 2011. 
decided to save it. In July 2011 they became owners of the tower and prepared a project for EU funding (ROP Jihozápad programme). They were successful and in February 2012 received funding of CZK 4.8 million. However, the project budget was 5.6 million, so the Club had to make up the difference elsewhere. ${ }^{21}$ In Tachov region around 2012 there were plans to build several lookout towers, one of which is the one on Havran hill. ${ }^{22}$

The third phase of media presentation covers the years 2013-2015. Reconstruction of the tower took place from 2013 to spring 2014 (Figure 3). The opening ceremony took place in June 2014 and the promotion of the newly open tower went on throughout 2015, sometimes as a part of the boom in lookout towers in the region ${ }^{23}$ or as an attraction on cycling paths accessible by special buses for cyclists. ${ }^{24}$ The reconstruction itself was definitely not an easy task; it involved a huge amount of work. During the reconstruction the Club also had to contend with thieves (somebody stole a backhoe loader ${ }^{25}$ and tons of steel ${ }^{26}$ ) and other problems caused by bad weather in $2013 .{ }^{27}$ The lookout tower itself was opened to the public in 2014 on the Upper Palatine Forest Day on the 14th of June. The programme for the day included the ceremonial opening of the tower, a theatre performance, competitions for children, presentations by various clubs and institutions and a Royal Rangers performance. ${ }^{28}$ Local authorities (e.g. mayors, director of Protected Landscape Area) were present at the opening giving their formal support to the transformation of Havran into a lookout tower, however their previous attitudes to this initiative were rather neutral.

21 Havran málem padl, zachrání ho dotace / Havran nearly fell, it will be saved by a grant, 2013.

22 E.g. Tachovsko se může brzy stát krajem rozhleden a vyhlídek / Tachov region can soon become a region of lookout towers and scenic views, 2012.

23 E.g. Věže rostly jako houby po dešti / Towers sprang up like mushrooms after rain, 2015.

24 Obce lákají na atrakce a cyklobus / Municipalities are enticing (people) with attractions and a special bus for cyclists, 2015.

25 Nadšenci nabízejí odměnu tomu, kdo najde ukradený bagr nebo zloděje / Enthusiasts offer a reward to whomever finds the stolen excavator or the thief, 2013.

26 Věž stojí, nadšence nezlomili ani zloději / The tower is standing, not even thieves could stop the enthusiasts, 2014.

27 Opravovaná rozhledna čelí nájezdům zlodějů i počasí / Repaired lookout tower faces thieves and bad weather, 2013; K Šibeničnímu vrchu, Milírum a Březince se brzy přidá Havran / Havran will soon join Šibeniční vrch, Milíře and Březinka, 2013.

28 Den Českého lesa redakčním objektivem / The Day of the Upper Palatine Forest: An Editor's View, 2014. 
Unsurprisingly the last phase of media coverage in 2016-2018 is mostly represented by mentioning Havran as a lookout tower or point of interest for tourists or a point on a cycling path or race. Unlike in the previous period, the history of the tower is an important topic in only one article. ${ }^{29}$

In the previous part we tried to summarize the tower's transformation process, or the beginning of its new life, if you will. Now we will shift our attention to the exhibition, which provides context for the former military structure now changed into a tourist attraction. The Club's intentions about how to present the tower developed over time. The idea to preserve the tower and make it into a lookout tower and Iron Curtain memorial appears in the media for the first time in $2011 .{ }^{30}$ In 2012 this idea was extended to include 'exhibits about history or about surrounding nature' at the tower, and the Club also considered exhibiting art objects made of wood and iron. They also wanted to 'remember the recent past on information boards and considered using small artefacts in the exhibition,' but no weapons or tanks or similar things. ${ }^{31}$ After the tower re-opened articles appeared in the media describing an 'exhibition about the Iron Curtain and the people who decided to go west to be able to live free ${ }^{\prime 32}$ and 'panels with interesting examples of people's attempts to cross the state border' ${ }^{33}$ The only mention in 2015 was a short notice informing that the programme for the opening of the summer season will also include a presentation from an exhibition called 'The Iron Curtain'. ${ }^{34}$

During our first visit to the reconstructed tower in the autumn of 2014, we could see the whole exhibition. The exhibition is also available in photographs on the website of the Institute of Contemporary History of the

29 Kdysi prísně utajované pracoviště dnes poskytuje překrásný výhled na Český les a Šumavu / Once top-secret site now offers a splendid view of the Upper Palatine Forest and Bohemian Forest, 2017.

30 Havran se bourat nebude / Havran will not be demolished, 2011.

31 Klub opraví dominantu Českého lesa, bývalou hlásku Havran / The Club will repair the dominant feature of the Upper Palatine Forest, former military station of Havran, 2012; Havran se začne měnit. Klub už pracuje na př́pravě projektu / Havran will start to change. The Club is working on a project, 2012.

32 Záchrana se podařila. Rozhledna už slouží veřejnosti / The rescue succeeded. The lookout tower is serving the public, 2014; Ukradený bagr, stohy papírů. Věž ale přežila / Stolen excavator, piles of paper. However, the tower survived, 2014.

33 Z bývalé vojenské hlásky na kopci Havran na Tachovsku udělali nadšenci rozhlednu / Enthusiasts made a lookout tower from a former military station on the Havran hill in the Tachov region, 2014.

34 Dobrá zpráva pro Tachovsko / Good news for Tachov region, 2015. 
Czech Academy of Sciences. ${ }^{35}$ It consists of ten panels, eight about the cases of crossing the Iron Curtain border (in the brackets are the Czech names and their German translations): Zdeněk Bakule; Tank of freedom (Tank svobody / Panzer der Freiheit); Couriers in hot-air balloons (Kurýři v balónech / Ballonkuriere); Josef Škop; The sledge of Antonín Krejcar (Saně Antonína Krejcara / Der Schlitten des Antonin Krejcar) and Flight to freedom (Let na svobodu / Flug in die Freiheit); Hartmuth Tautz and Soldiers in a self-propelled gun (Vojáci v samohybném děle / Soldaten im selbstfahrenden Geschütz.)

The two remaining panels are about the history of the tower and its reconstruction and about the Iron Curtain; they are titled History, Reconstruction, Havran in numbers (original: Historie, Rekonstrukce, Havran v č́slech) and Iron Curtain (Železná opona / Der eiserne Vorhang).

At the top of each panel is the heading Havran Lookout Tower, and at the bottom is the EU flag, logo of the Fund and a short text that the project was paid for with EU funding. The panel topics are described in texts and visual materials: archive photographs and in one case also a picture of a newspaper article. When we visit the reconstructed tower, the lower part had the panel History, Reconstruction, Havran in numbers (Figure 4a) and two other panels: a photograph of Havran from 2008, showing the state of the tower when the army was considering its demolition with a note stating that the reconstruction happened thanks to the Club and naming all members (Milan Volf, Miroslav Hověžák, Jan Kárník and Pavel Janoušek) (Figure $4 \mathrm{~b}$ ) and a board with the names of the contractor (Stavmonta s. r. o), sponsor (the Club) and designer (AVE architekt a. s.) (Figure 4c). The fourth level of the tower held the other panels: eight about attempts to cross the border to the West and one about the Iron Curtain (Figure 5).

The first panel informs visitors of the purpose of the tower, describing how it used to be a Czechoslovak army intelligence station for radiotechnical surveillance and how its main purpose was to monitor military radars or navigation systems of NATO airplanes. Then it offers a summary of the history and use of the tower with a few lines about military units who worked in the tower ('History'). Another part ('Reconstruction') is devoted to a summary of the reconstruction process, how long it took

35 Pamětní místa na komunistický režim Jak poznáváme a reflektujeme dobu nesvobody 1948-1989 a jak si toto období připomínáme na veřejných prostranstvích? - Havran / Memorial sites for the Communist regime: How do we get to know and reflect on the totalitarian period 1948-1989 and how do we remember this period in public spaces? - Havran http://www.pametnimista. usd.cas.cz/rozhledna-havran/ [retrieved 2019-03-07]. 
and how much it cost. The last part ('Havran in numbers') presents facts like altitude, the tower's height and weight and how many litres of paint it needed.

The fourth level of the tower held the rest of the panels. All are both in Czech and German, which is highly relevant in the regional context because the majority of visitors speak Czech or German. On the first panel about the Iron Curtain visitors could read about the development of the border surveillance after the Communist takeover (1948), which is put into context with the escapes to the West. The authors review the development of the border infrastructure and also give numbers of how many people were arrested when trying to cross the border in 1950-1989, how many people were killed and how many soldiers died in the line of duty and how.

The vast majority of the exhibition shows attempts to cross the border. As described on the eponymous panel, Zdeněk Bakule unsuccessfully attempted to cross the border in a hot air balloon in 1985. Another panel called 'Tank of freedom' tells the story of how a whole group in an armoured transporter successfully escaped to the West in 1953. The panel 'Couriers in hot-air balloons' gives examples of spies who crossed the border in balloons in 1953. The panel 'Josef Škop' tells the story of a man who died trying to cross the border under the Elbe River in a homemade diving suit. The fifth panel, 'The sledge of Antonín Krejcar', tells another story of an attempt to escape. A group of people hid in the hay on the sledge pulled by a horse in 1981 and successfully made it to the West. The panel 'Flight to freedom' tells the story of former Royal Air Force members who successfully escaped and landed with three airplanes in Erding, Germany in 1950. The seventh panel - 'Hartmut Tautz' - tells the tragic story of a young man who was fatally injured by border guard dogs during his attempt to cross the border in summer 1986, later dying in hospital. The last panel, 'Soldiers in a self-propelled gun', is about an unsuccessful attempt to cross the border in an armoured vehicle in 1964 .

It is unfortunate that we mostly do not know the names of the authors of these texts and the provenance of the visuals. The idea behind the exhibition is probably to accompany or frame the reconstructed tower with information panels about the tower and put it in the context of the surrounding environment, once the restricted zone of the Iron Curtain. The texts are short, easy to read, and illustrated with visuals. The exhibition is not large and is trying to present history that is not well known and that has relevance to the surrounding area. However, the choice of topics could cause some dispute as a part of the heritagization process that follows. 


\section{Discussion: Sense of the place before and after}

In the early 1960 s a specialized military facility was built on Havran and later gradually extended and developed. The base was used for military radio surveillance and intelligence and run by an elite and 'top secret' unit of the Czechoslovak army and never had anything to do with guarding the Iron Curtain. The situation was exactly opposite: Havran tower was (especially starting in the 1970s) under strict supervision of border guards, while neither the border guards nor the general public had any idea about the actual purpose of the tower.

After the facility was abandoned in the early 1990s Havran quickly devolved into rusty ruins, its wooden structures crumbled, and its barbed wire fences and other infrastructure were covered with wild vegetation. As documented in the memories of local people or in contemporary media, this absence of care turned Havran into an unofficial monument to the highly controversial military past of the former Czechoslovakia. It was both a place of adventure and a place of decay, theft and a destination for emerging dark tourism (for this concept see e. g. Foley - Lennon 2000). Havran stood for almost 20 years as a material monument to the end of the Cold War, manifested by its state as a ruin, no longer in use, no longer needed. At the same time its real purpose and use were quickly forgotten and Havran tower began to be generally and erroneously connected with Iron Curtain ruins. Only a very small group of former soldiers who served there during their military service in the 1960s, 1970s and 1980s, kept the memory of the place to some degree, although without much public response.

The story got complicated after the Czech army decision to demolish the tower in 2009, and in 2011 a local bottom-up initiative began preparations to save and rebuild Havran. The newspaper article reported the Club's intentions as described by Club member Jan Kárník: 'We believe that the tower on Havran, once a means of radio-electronic war, will live its new life, bring joy and connect people from both sides of the border.' ${ }^{36}$ The idea was to build the lookout tower and to frame it as a memorial for the Iron Curtain by adding the exhibition. As stated above the exhibition has 10 panels but only one about the history of the Havran tower itself. One is dedicated to the Iron Curtain in general and eight to successful and unsuccessful attempts to escape from the Soviet bloc. Some are tragic stories of death at the border and imprisonment; some showcase escapes with the use of spectacular technical innovations. Such stories can attract

36 Věž stojí, nadšence nezlomili ani zloději / The tower is standing, not even thieves could stop the enthusiasts, 2014. 
the attention of the visitors to think about the past, but on the other hand the majority of people who successfully escaped did it in a different and far less 'entertaining' way. Moreover, none of the stories presented is directly linked to Havran and only one single story ('Tank of freedom') has a relation to the Upper Palatine Forest as it happened near Nemanice approx. $50 \mathrm{~km}$ away from Havran. It is therefore clear that although the Club members were aware of the real history of Havran, they consciously chose the Iron Curtain as the theme of the exhibition as a more attractive topic to tourists.

In addition, this way of presenting the Iron Curtain through spectacular and tragic stories (sometimes both at once) can be regarded as very typical and even unimaginative, as can be seen in dozens of museums and monuments not only in the Czech Republic ${ }^{37}$ but also in Germany (e.g. Ausstellungsbegleitband 2010: 72-75). It is widely present as an attractive appendix in books that otherwise deal with completely different (e.g. technical) aspects of the Iron Curtain (Ritter - Lapp 2011: 67-68, 73-74, 76-77) and it can lead to the creation of dubious publications whose only purpose is to entertain and frighten the reader (Pejčoch 2008; Pejčoch 2009; Pejčoch 2011). In this regard, we consider the exhibition a questionable way of 'heritagization' of the place, only vaguely connected to the local or regional heritage of military and Iron Curtain history. Unfortunately, we are not able to collect and discuss any interpretations of the tower by visiting tourists because there is no logbook at the site that could be used for this purpose. When focusing on the response of former soldiers serving at the site towards the change the tower has undergone, we can build on the discussions on fora at Vojensko.cz project. The vast majority of soldiers and border guards are very proud and happy that the tower has been saved, but they do not make any comments on the exhibition itself (http://www.vojensko.cz/stanoviste-havran [retrieved 2019-02-05]). On the other hand, the Club was very successful in saving and rebuilding the tower into a lookout tower and popular tourist destination, which itself is an extraordinary achievement. They preserved a tower that would otherwise disappear and managed to incorporate it into the tourist infrastruc-

37 See the list and thorough documentation on Czech Iron Curtain and Cold War monuments, memorials and exhibitions at http://www.pametnimista. usd.cas.cz [retrieved 2019-02-05]. We do not aim here to compare Havran with other military monuments in the Czech Republic, however the way the tower was saved and transformed is not unique and is comparable to several other (esp. privately owned and managed) Cold War, Iron Curtain, police and military museums in the Czech Republic. The closest 'relatives' in this sense are former military intelligence towers at Dyleň and Poledník, now also changed into lookout towers. 
ture, which is accessible to all for free. It is preserved as itself and it gives opportunity to all visitors to enjoy a beautiful view over the surrounding wooded landscape.

\section{Conclusion}

Saving the tower and its reconstruction was a local bottom-up activity, which was provoked by the Army's decision to demolish the tower. The place is certainly worth saving as a piece of 20th century history as well as to improve the tourist infrastructure for the region. However, the exhibition is of questionable value, as the panels with stories about spectacular escapes across the Iron Curtain or tragic unsuccessful attempts situated in the tower could cause misunderstanding among visitors, who might conclude that the tower was part of the infrastructure of the Iron Curtain. This is especially the case at this place, whose purpose was held in strict secrecy for decades and, as we saw, was not entirely clear even to the former border guards. The process of heritagization of the Havran tower is thus connected with the acceleration of the process of forgetting the past. Local military heritage (military intelligence tower), which is known to the Club, but is possibly interesting only for a small group of enthusiasts, was consciously put into the background in favour of presenting far more popular and easily understood issues of the Iron Curtain. In the process of building a tourist lookout tower and building a monument the place lost its appearance of military structure, as the remaining barbed wire, fences, barracks, and dog kennels were taken away and new meanings ascribed to the place through the exhibition, which is not connected to the past purpose and use of the tower.

Since it is a very popular tourist place and the intention of the Club to present it and frame with exhibition as 'Iron Curtain Memorial' is successful, we can consider Havran tower as a heritage site, which is - even if it is not under official heritage protection - very much directed to become a part of newly established and questionable 'authorized heritage discourse' (Smith 2006), which is different from the factual history of the place. That said, we would like our article to serve as a starting point for a critical discussion of the secondary use of similar post-military structures and the heritagization processes they undergo. It raises questions on how to present this recent past, and how to frame such sites. Such projects should be considered as a part of the spatial production of social memory - how we remember the recent past. 


\section{Archival sources}

ABS - Archiv bezpečnostních složek, fond 5. brigáda PS Cheb, i. č. 329, 357-359, 362, 1335-1340

\section{References}

Ausstellungsbegleitband Grenzlandmuseum Eichsfeld. 2010. Duderstadt: Grenzlandmuseum Eichsfeld.

Banaszkiewicz, Magdalena - Graburn, Nelson - Owsianowska, Sabina. 2017. Tourism in (Post)socialist Eastern Europe. Fournal of Tourism and Cultural Change 15: 109-121, DOI: 10.1080/14766825.2016.1260089.

Brewer, Devon D. 2002. Supplementary Interviewing Techniques to Maximize Output in Free Listing Tasks. Field Methods 14: 108-118.

Bernard, Russel H. 2006. Research Methods in Anthropology: Qualitativeand Quantitative Approaches. Lanham: Rowman \& Littlefield Publishers.

Blight, David W. 2009. The Memory Boom: Why and Why Now? In: Boyer, Pascal - Wertsch, James (eds.): Memory in Mind and Culture. Cambridge, New York, Melbourne etc.: Cambridge University Press: 238-251.

DeSilvey, Caitlin. 2017. Curated Decay: Heritage beyond Saving. Mineapolis: University of Minessota Press.

Drechsel, Benjamin. 2010. The Berlin Wall from a visual perspective: comments on the construction of a political media icon. Visual Communication 9: 3-24, DOI: 10.1177/1470357209352947.

Dubánek, Martin - Lakosil, Jan - Minařík, Pavel. 2011. Utajená obrana železné opony; Československé opevnění 1945-1964. Praha: Mladá fronta.

Eckert, Astrid M. 2011. Greetings from the Zonal Border. Tourism to the Iron Curtain in West Germany. Zeithistorische Forschungen / Studies in Contemporary History 8: 9-36.

Edl, Jan. 2013. Nepevná hráz míru a socialismu. Ochrana státní hranice v letech 1948-1949 ve světle archiválií ONV Tachov. In: Vaněk, Pavel (ed.): Ochrana státní hranice 1948-1955. Brno: Technické muzeum v Brně: 80-91.

Fatková, Gabriela et al. 2014. Tachovsko: Krajina v paměti / pamět' v krajině. Plzeň: Západočeská univerzita.

Foley, Malcolm - Lennon, John J. 2000. Dark Tourism: the Attraction of Death and Disaster. London: Thomson Learning.

Folklore: Electronic fournal of Folklore 70. 2017. Special issue: Small Places, Large Issues, guest editors: Seljamaa, Elo-Hanna - Czarnecka, Dominika - Demski, Dagnosław. 
Graham, Brian - Howard, Peter. 2008. Introduction: Heritage and Identity. In: Graham, Brian - Howard, Peter (eds.): The Ashgate Research Companion to Heritage and Identity. Aldershot, Burlington: Ashgate: 1-15.

Hamperl, Wolf-Dieter. 1996. Vertreibung und Flucht aus dem Kreis Tachau in Egerland: Schicksale in Berichten, Dokumenten und Bildern. Trostberg: A. Erdl.

Hamperl, Wolf-Dieter. 2004. Die verschwundenen Dörfer im ehemaligen Bezirk Tachau im südlichen Egerland: Dokumentation von Zerstörung und Verfall der Egerländer Kulturlandschaft in der Mitte Europas nach 1946. Band III. Altenmarkt.

Harlov-Csortán, Melinda. 2017. From the Borderland of the Iron Curtain to European and World Cultural Heritage. Folklore: Electronic Fournal of Folklore 70: 193-224.

Hlávka, Jiří - Kadera, Jiří. 2010. Historie železářství a uhlírství v Českém lese. Planá: Hornicko-historický spolek.

Hofmann, Gustav. 1991. Nové osady vzniklé na území Plzeňska v letech 1654-1854. Minulostí Západočeského kraje 27: 141-170.

Hř́́bal, Antonín. 2014. Věž na Havranu přežila a poslouží pro radost. Tachovský deník 137 (13. 6. 2014): 3.

Ilčík, Václav. 2013. 7. radiotechnická brigáda zoláštního určení Zbiroh: Zapomenutá elektronická válka podél železné opony. Brno: Václav Ilčík (vlastním nákladem).

Ilčík, Václav. 2017. Z Kralovic a Zbiroha až do Opavy: Vojáci elektronické války. Svazek 1., 2. Brno: Václav Ilč́́k (vlastním nákladem).

Janeček, Petr. 2015. Evropská etnologie a koncept nehmotného kulturního dědictví. Národopisná revue 25: 273-282.

Jílek, Tomáš - Jílková, Alena et al. 2006. Železná opona: československá státní hranice od fáchymova po Bratislavu v letech 1948-1989 Praha: Baset.

Kotrbatá, Ivana. 2010. „Ještě je 400 míst volných v tachovském okrese!“ Př́spěvek $\mathrm{k}$ „malým dějinám“ reemigrace a dosídlení Tachovska v narativních interview na začátku 21. století. Českýlid 97: 265-280.

Kovařík, David. 2006. Proměny českého pohraničí v letech 1958-1960. Demoliční akce v českém pohraniči se zréetelem k vývoji od roku 1945. Brno: Prius.

Köferl, Josef . 1890. Bezirk Tachau. Eine Heimatskunde. Tachau: Hermann Holub.

Lowe, David - Joel, Tony. 2013. Remembering the Cold War: Global Contest and National Stories. London: Routledge, DOI: 10.4324/9781315850405.

Owsianowska, Sabina. 2017. Tourist narratives about the dissonant heritage of the Borderlands: the case of South-eastern Poland. 
Journal of Tourism and Cultural Change 15: 167-184, DOI:

10.1080/14766825.2016.1260125.

Pauknerová, Karolína - Woitsch, Jiř́i. 2016. Educational trails as landscape memory agents in the West Bohemian border region. In: Zückert, Martin - Hein-Kircher, Heidi (eds.): Migration and Landscape Transformation: Changes in Central and Eastern Europe in the 19th and 20th Century. München: Vandenhoeck \& Ruprecht 2016: 175-202. Pearson, Chris. 2012. Researching Militarized Landscapes: A Literature Review on War and the Militarization of the Environment. Landscape Research 37: 115-133, DOI: 10.1080/01426397.2011.570974.

Pearson, Chris - Coates, Peter - Cole, Tim (eds.). 2010. Militarized Landscapes. From Gettysburg to Salisbury Plain. London, New York: Continuum.

Pejčoch, Ivo. 2008. Hrdinové železné opony. Cheb. Svět křídel.

Pejčoch, Ivo. 2009. Útěky za železnou oponu. Cheb. Svět kř́ídel.

Pejčoch, Ivo. 2011. Přechody přes železnou oponu. Cheb. Svět kř́ídel.

Petrášová, Markéta. 1984. Př́íchod ukrajinských přesídlenců z Rumunska na Tachovsko. Materiály k problematice novoosídleneckého pohraničí, sv. 1. Zpravodaj koordinované sítè vědeckých informací pro etnografii a folkloristiku 4: 58-61.

Petrášová, Markéta. 1985. Ukrajinci-Rusíni v západních Čechách. Etnické procesy v novoosídleneckém pohraničí - dělnictvo v etnických procesech, sv. 1. Zpravodaj koordinované sitè vědeckých informací pro etnografii a folkloristiku 5: 111-128.

Poria, Yaniv - Ashworth, Gregory. 2009. Heritage tourism - Current resource for conflict. Annals of Tourism Research 36: 522-525.

Procházka, Zdeněk. 2009. Sklárství v Českém lese na Domažlicku a Tachorsku. Místopis skláren, brusíren a leštíren Domažlice: Nakladatelství českého lesa.

Procházka, Zdeněk. 2011. Putování po zaniklých místech Českého lesa. II., Tachorsko. Osudy 45 zaniklých obcí, vsí a samot Domažlice: Nakladatelství Českého lesa.

Pulec, Martin. 2001. Nástin organizace a činnost ozbrojených pohraničních složek v letech 1948-1951. Securitas Imperii 7: 55-96.

Pulec, Martin. 2006. Organizace a činnost ozbrojených pohraničních složek. Seznamy osob usmrcených na státních hranicích 1945-1989. Praha: Úřad dokumentace a vyšetřování zločinů komunismu.

Ritter, Jürgen - Lapp, Peter Joachim. 2011. Die Grenze. Ein Deutsches Bauwerk. Berlin: Ch. Links Verlag.

Robertson, Iain J. M. (ed.). 2016. Heritage from below. London and New York: Routledge. 
Schmidt, Leo - von Preuschen, Henriette (eds.). 2005. On Both Sides of the Wall. Preserving Monuments and Sites of the Cold War Era. Berlin, Bonn: Westkreuz-Verlag.

Schofield, John - Cocroft, Wayne (eds.). 2009. A Fearsome Heritage. Diverse Legacies of the Cold War. Walnut Creek: Left Coast Press.

Schuster, Franz. 1962. Tachau-Pfrauberger Heimat. Weiden: Verein zur Erhaltung altern Kulturgutes des Tachauer Gebietes in Weiden.

Slavíková, Anděla - Vaněk, Pavel. 2008. Prozatímní inventář k archionímu fondu 2342. 5. brigáda PS Cheb. (1913) 1951-1992. Praha: Archiv bezpečnostních složek.

Smith, Laurajane. 2006. Uses of Heritage. London, New York: Routledge.

Smith, Laurajane. 2012. Discourses of heritage: implications for archaeological community practice. Nuevo Mundo Mundos Nuevos. DOI: 10.4000/nuevomundo.64148.

Staněk, Tomáš. 1991. Odsun Němců z Československa 1945-1947 Praha: Academia.

Stručný přehled dějin Pohraniční stráže. 1986. Praha: Naše vojsko.

Swyngedouw, Erik. 2010. Apocalypse Forever? Post-political Populism and the Spectre of Climate Change. Theory, Culture \& Society 27: 213-232, DOI: 10.1177/0263276409358728.

Vaněk, Pavel. 2004. K vývoji ženijnětechnického zabezpečení státní hranice v letech 1951-1955. Sborník Archivu Ministerstva vnitra 2: 183-229.

Waterton, Emma - Watson, Steve (eds.). 2015. The Palgrave Handbook of Contemporary Heritage Research. Basingstoke, New York: Palgrave Macmillan.

Woitsch, Jiř́. 2016. Etnologie studené války v České republice: témata, př́stupy, metody. Národopisný věstník 75: 5-30.

Zíková, Tereza - Fatková, Gabriela. 2014. Lokální identita a pamět' krajiny: významné krajinné komponenty v perspektivě aktérů. Národopisná revue 24: 203-216.

\section{Websites}

Klub vojenské historie Tachov (Club of military history Tachov) Havran tower [online]. [2019-03-05] Retrieved from: http://rozhlednahavran.cz/web/kontakt/

The Central List of Cultural Monuments of the Czech Republic of the National Heritage Institute [online]. [2019-02-18] Retrieved from: https://www.npu.cz/en/NPU-and-heritage-conservation/historic-buildings-conservation-management/the-monument-fund/immovable-heritage 
Vojensko.cz, Havran - Photograph gallery of former Border guards' and Czechoslovak People Army (Czech: Fotogalerie objektů bývalé Pohraniční stráže a Československé lidové armády) with lines of conversation under the galleries [online]. [2019-02-05] Retrieved from: http:// www.vojensko.cz/stanoviste-havran

Pamětní místa na komunistický režim Jak poznáváme a reflektujeme dobu nesvobody 1948-1989 a jak si toto období připomínáme na veřejných prostranstvích? - Havran [online]. [2019-03-07] Retrieved from: http://www.pametnimista.usd.cas.cz/rozhledna-havran/

\section{Newspaper articles}

Opuštěná vojenská věž stojí na Havranu, 10. 10. 2002, Večerník Praha, Vladimír Pohorecký, p. 3, published also in Střední Čechy.

Podél “železné opony” na Havran, 2. 8. 2007, Mladá fronta DNES - plzeňský kraj, Aleš Tolar, p. 5., published also in Mladá fronta DNES - karlovarský kraj.

Vrch Havran nahnal turistům pořádný strach, 11. 2. 2008, Tachovský deník, David Růžička, p. 2.

Havran chátrá, může tam jít o život, 10. 10. 2009, Tachovský deník, Jiří Kohout, p. 2.

Výlet na Šumavu, 30. 10. 2010, Strakonický deník, Tomáš Nohejl, p. 8.

Havran se bourat nebude, 3. 12. 2011, Tachovský deník, Jiří Kohout, p. 1, published also in Klatozský deník.

Tachovsko se může brzy stát krajem rozhleden a vyhlídek, 3. 2. 2012, Tachovský deník, Jiří Kohout, p. 2.

Klub opraví dominantu Českého lesa, bývalou hlásku Havran, 1. 6. 2012, Tachorský deník, Josef Holek, p. 1., shortened version published also in Plzeňský deník a Plzeňský deník - jîh.

Havran málem padl, zachrání ho dotace, 2. 5. 2013, 5plus2 - Tachorsko, Zdeňka Lochmanová, p. 3.

Nadšenci nabízejí odměnu tomu, kdo najde ukradený bagr nebo zloděje, 7. 6. 2013, plzen.iDNES.cz, Petra Petř́íková, no. 158.

Opravovaná rozhledna čelí nájezdům lupičů i počasí, 12. 6. 2013, Právo jihozápadní Čechy, Jan Švábek, p. 10.

K Šibeničnímu vrchu, Milírům a Březince se brzy přidá Havran, 8. 8. 2013, 5plus2 - Tachorsko, Zdeňka Lochmanová, p. 3.

Den Českého lesa redakčním objektivem, 15. 6. 2014, denik.cz-plzeňský kraj, author not stated, no. 166., published also in Tachovský deník. 
Záchrana se podařila. Rozhledna už slouží veřejnosti, 18. 6. 2014, 5 plus2. $c z$ - Tachovsko, Ladislav Vaindl, no. 169.

Věž stojí, nadšence nezlomili ani zloději, 20. 6. 2014, 5plus2 - Rokycansko, author not stated, p. 4.

Z bývalé vojenské hlásky na kopci Havran na Tachovsku udělali nadšenci rozhlednu, 18. 7. 2014, zprazy.rozhlas.cz, Lukáš Milota and Simona Bartošová, no. 199

Věže rostly jako houby po dešti, 24. 4. 2015, Mladá fronta DNES Plzeňský kraj, Ladislav Vaindl, p. 3.

Dobrá zpráva pro Tachovsko, 13. 6. 2015, Tachovský deník, (jk), p. 1.

Obce lákají na atrakce a cyklobus, 26. 5. 2015, Tachorský deník, Antonín Hř́bal, p. 1.

Kdysi př́sně utajované pracoviště dnes poskytuje překrásný výhled na Český les a Šumavu, 22. 10. 2017, novinky.cz, Jan Kaše, no. 295.

Havran se začne měnit. Klub už pracuje na př́pravě projektu, 3. 8. 2012, Tachovský deník, Josef Holek, p. 1., shortened version published also in Plzeňský deník.

Ukradený bagr, stohy papírů. Věž ale přežila, 20. 6. 2014, 5plus2 - Tachovsko, Ladislav Vaindl, p. 4., published also in 5plus2 - Domažlicko.



Figure 1 Havran intelligence tower project from 1980s (source: ABS - Archiv bezpečnostních složek) 


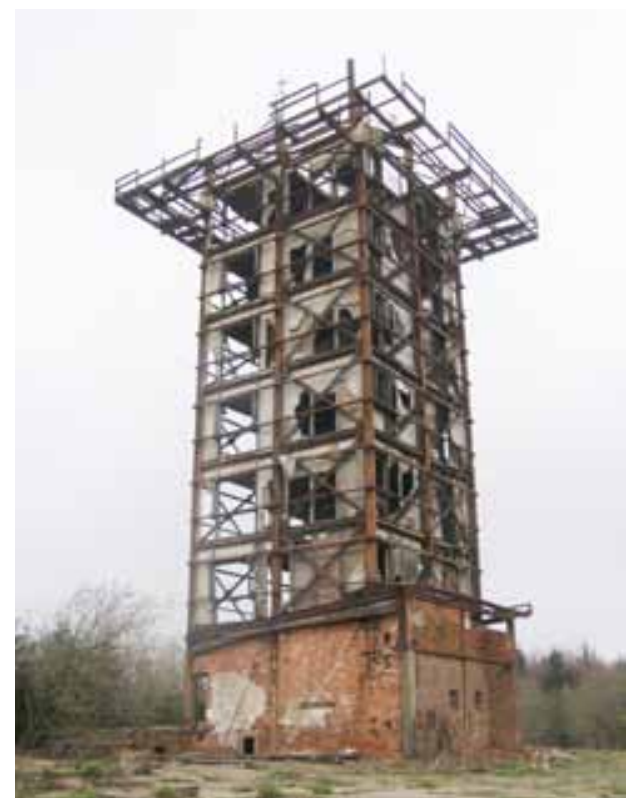

Figure 2 Ruins of Havran in May 2013 shortly before the renovation (source: authors, 2013)

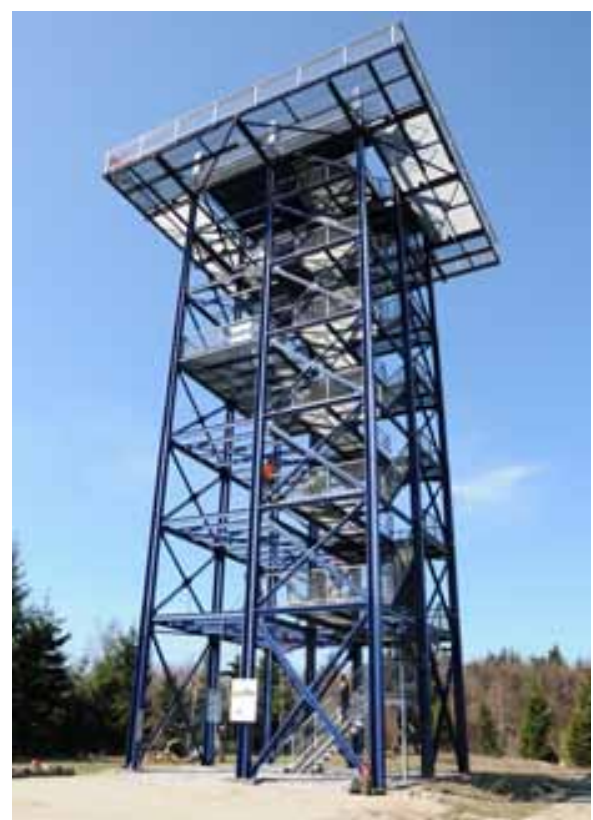

Figure 3 Havran lookout tower in March 2019 (source: authors, 2019) 


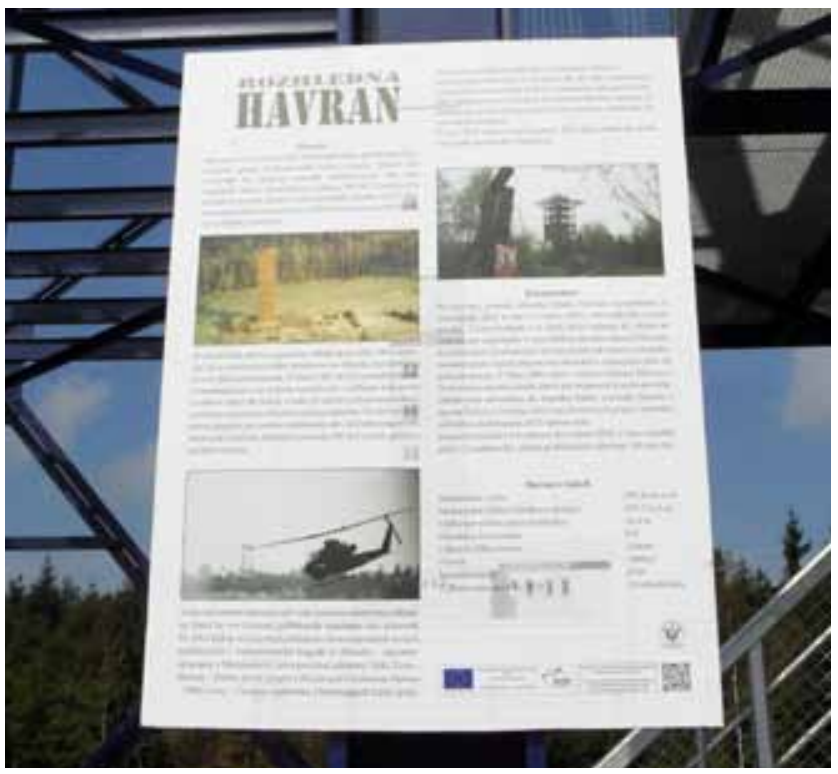

Figure 4a Information panels in the bottom part of the Havran tower (source: authors, 2014)

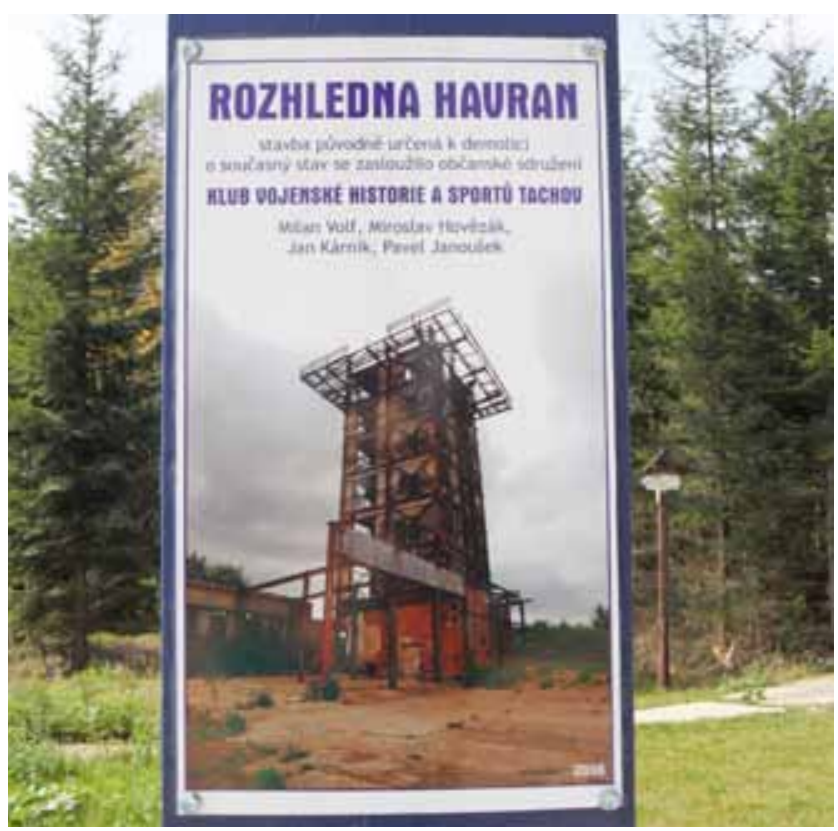

Figure $4 \mathrm{~b}$ Information panels in the bottom part of the Havran tower (source: authors, 2014) 


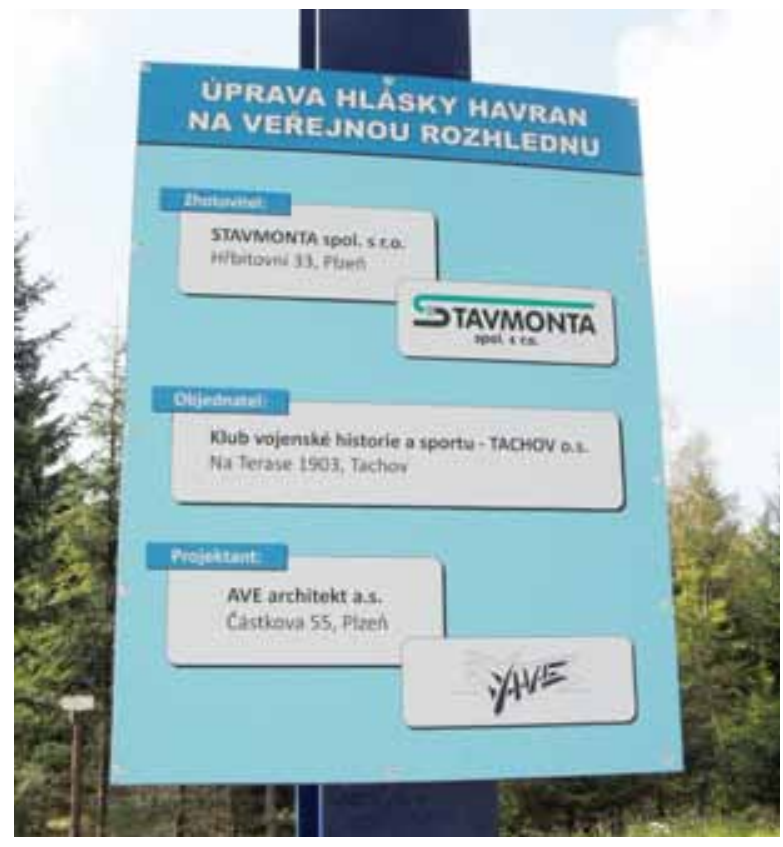

Figure 4c Information panels in the bottom part of the Havran tower (source: authors, 2014)

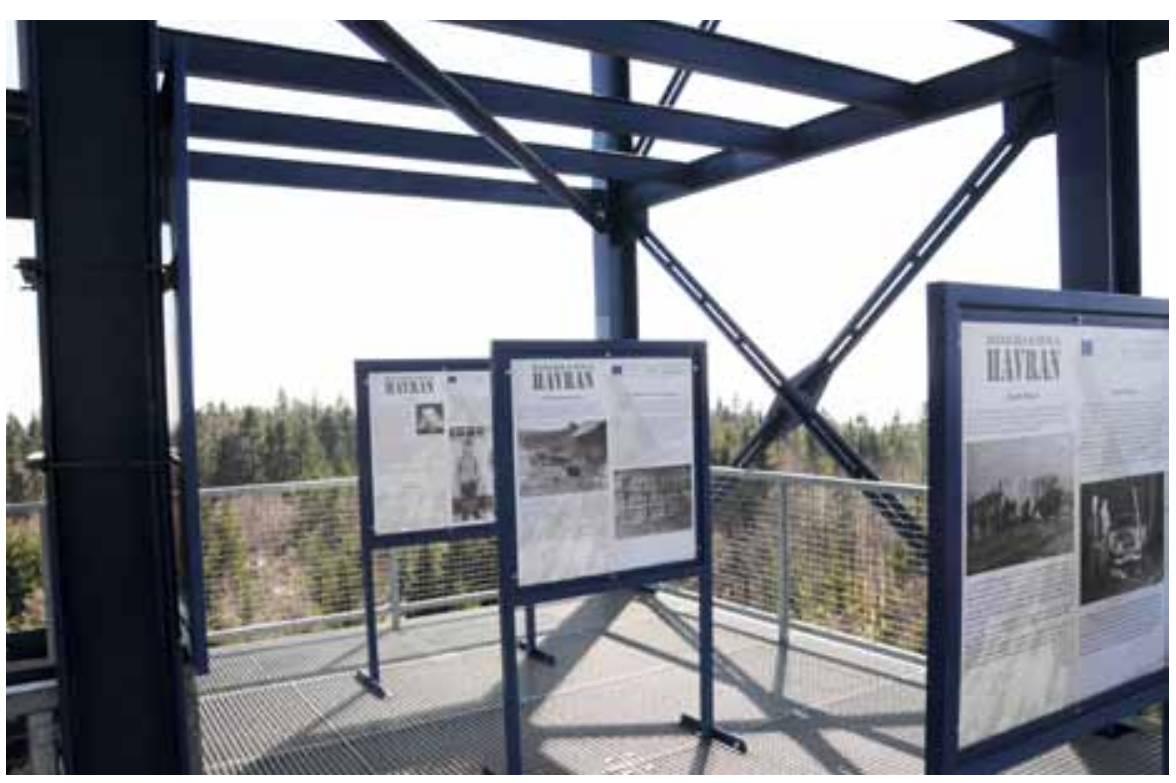

Figure 5 Exhibition in the Havran tower (source: authors, 2019) 